\title{
Heating Wheat Gluten Promotes the Formation of Amyloid-like Fibrils
}

\author{
Margarita Monge-Morera,* Marlies A. Lambrecht, Lomme J. Deleu, Nikolaos N. Louros, \\ Frederic Rousseau, Joost Schymkowitz, and Jan A. Delcour
}

Cite This: ACS Omega 2021, 6, 1823-1833

Read Online

ABSTRACT: Amyloid fibrils (AFs) are highly ordered nanofibers composed of proteins rich in $\beta$-sheet structures. In this study, the impact of heating conditions relevant in food processing on $\mathrm{AF}$ formation of wheat gluten (WG) was investigated. Unheated and heated WG samples were treated with proteinase $\mathrm{K}$ and trypsin to solubilize the nonfibrillated protein, while protein fibrils were extracted with $0.05 \mathrm{M}$ sodium phosphate buffer ( $\mathrm{pH}$ 7.0) from the undissolved fraction obtained by the same enzymatic treatment. Conditions (i.e., heating at $78^{\circ}$ for $22 \mathrm{~h}$ ) resembling those in slow cooking induced the formation of straight fibrils (ca. $700 \mathrm{~nm}$ in length), whereas boiling WG for at least $15 \mathrm{~min}$ resulted in longer straight fibrils (ca. $1-2 \mu \mathrm{m}$ in length). The latter showed the typical green birefringence of AFs when stained with Congo red. Their X-ray fiber diffraction patterns showed

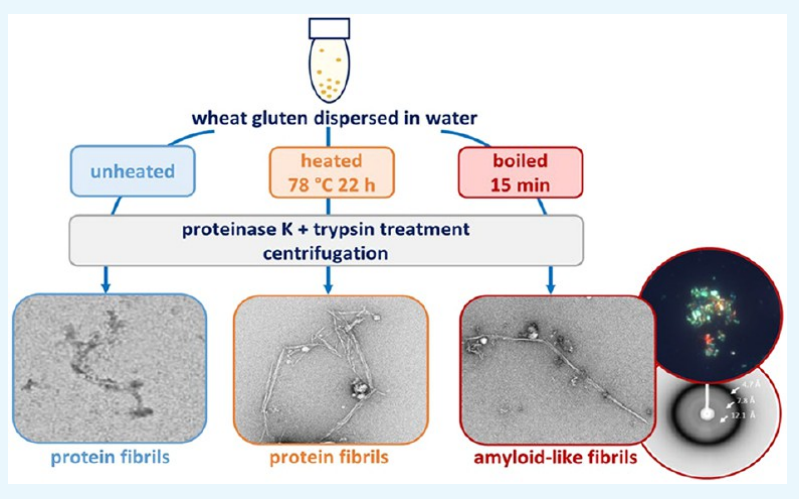
the typical reflection $(4.7 \AA)$ for inter- $\beta$-strand spacing. These results combined with those of Fourier transform infrared and thioflavin T spectroscopy measurements validated the identification of $\beta$-rich amyloid-like fibrils (ALFs) in dispersions of boiled WG. Boiling for at least 15 min converted approximately $0.1-0.5 \%$ of WG proteins into ALFs, suggesting that they can be present in heat-treated WG-containing food products and that food-relevant heating conditions have the potential to induce protein fibrillation.

\section{INTRODUCTION}

Wheat gluten (WG) provides unique viscoelastic properties to dough, which makes it an essential structural component in many baked products. ${ }^{1}$ The term WG refers to the cereal's storage proteins. They consist of gliadin and glutenin and are present in the endosperm. Gliadin is a heterogeneous mixture of single-chained proteins. Glutenin consists of peptide chains linked through disulfide bonds. ${ }^{2}$ WG is a coproduct of the industrial isolation of wheat starch and used in food ${ }^{3}$ and feed ${ }^{4}$ systems. Enhanced functionality (e.g., foaming or gelling capacity) of WG can facilitate its incorporation in food products. In that way, it can contribute to the increased use of plant proteins in food systems. An example of this is the successful (partial) replacement of egg white by WG hydrolysates in meringue recipes. ${ }^{5}$

Amyloid fibrils (AFs) are protein structures which hold much promise for improving the techno-functional properties of food proteins. ${ }^{6}$ This structure is also exploited by different organisms in Nature (e.g., Curli protein from Escherichia coli and protein Pmel17 involved in mammalian melanin synthesis) and has potential to be used as building blocks for bio-based materials. ${ }^{7,8}$ AFs are highly ordered fibrillar structures characterized by elongated $\beta$-sheets wherein the $\beta$-strands are stacked perpendicularly to the fibril axis and stabilized by hydrogen bonds. ${ }^{7,9}$ Protein (partial) unfolding or hydrolysis and subsequent exposure of aggregation prone regions are necessary for AF formation. ${ }^{10}$

Amyloid formation in food proteins has been studied in milk (e.g., $\beta$-lactoglobulin and bovine serum albumin), egg (e.g., lysozyme and ovalbumin), legume (e.g., soy and pea proteins), and cereal (e.g., rice, maize, and wheat) proteins. ${ }^{11,12}$ In these proteins, fibrillation has mainly been induced by heating at moderate temperatures and/or under acid conditions (e.g., 2.0) or in the presence of alcohols or chaotropic/reducing agents at neutral $\mathrm{pH}$, conditions rarely used in food processing. ${ }^{11,12}$ Nonetheless, the presence of AFs in duck- or goose-derived foie gras ${ }^{13}$ and in commonly boiled hen egg white ${ }^{14}$ has been proven. Drying, a common food processing condition, also induces the formation of amyloid-like fibrils ${ }^{15}$ (ALFs), which are fibrillar proteins of which strong evidence points toward their amyloid nature even if they do not necessarily meet all

Received: July 31, 2020

Accepted: December 14, 2020

Published: January 14, 2021 


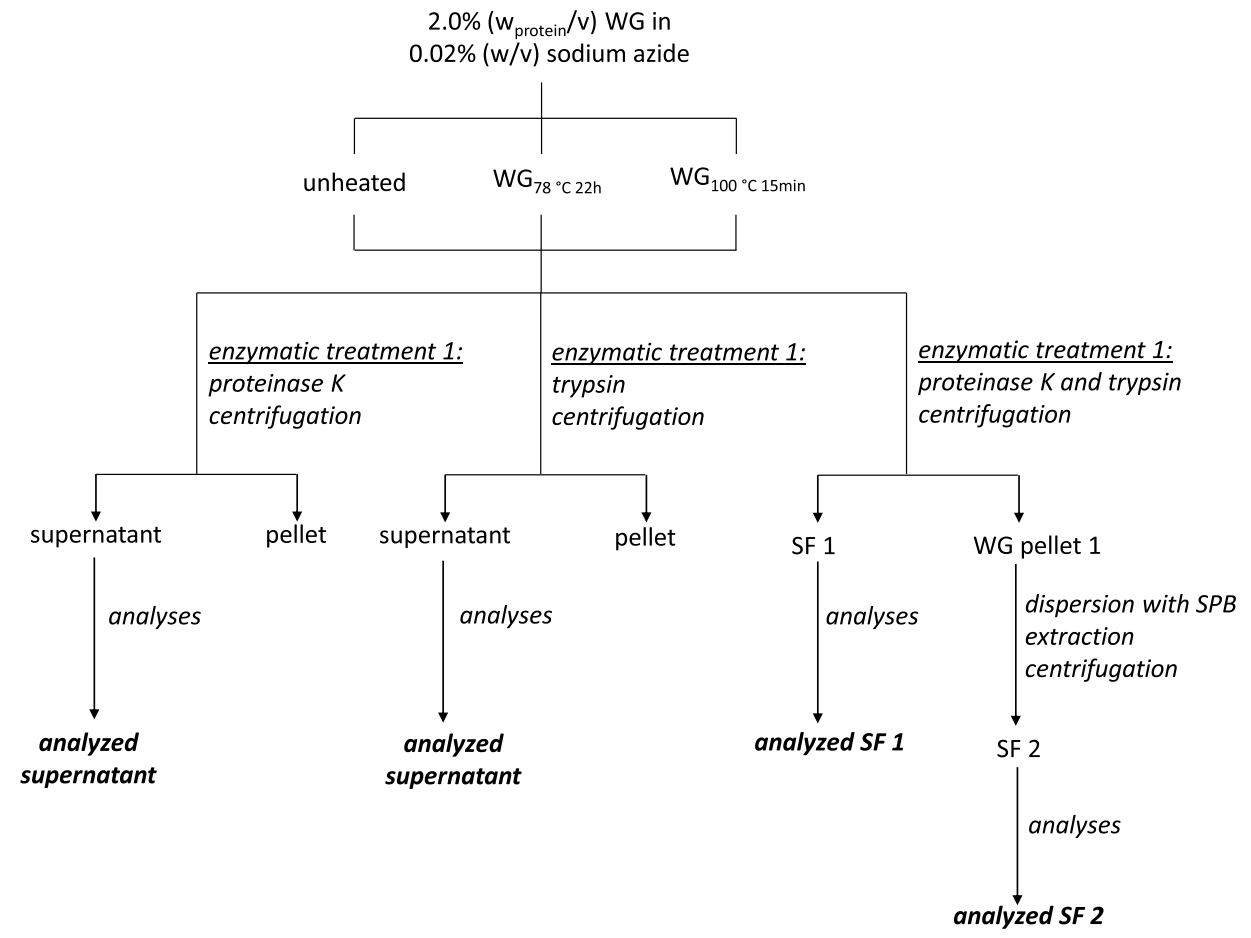

Figure 1. Experimental set-up for extracting protein fibrils from dispersions [containing $2.0 \%\left(\mathrm{w}_{\text {protein }} / \mathrm{v}\right)$ in $0.02 \%$ ( $\left.\mathrm{w} / \mathrm{v}\right)$ sodium azide] of unheated wheat gluten (WG), WG heated for $78^{\circ} \mathrm{C}$ for $22 \mathrm{~h}\left(\mathrm{WG}_{78^{\circ} \mathrm{C} 22 \mathrm{~h}}\right)$, or WG boiled for $15 \mathrm{~min}\left(\mathrm{WG}_{100^{\circ} \mathrm{C} 15 \min }\right)$. SF $x$ : supernatant fraction $x$, SPB: $0.05 \mathrm{M}$ sodium phosphate buffer ( $\mathrm{pH} 7.0)$.

classification criteria (i.e., high level of $\beta$-sheet structures, fibrillar morphology, green birefringence upon staining with Congo red dye, and typical cross- $\beta$ X-ray diffraction patterns) of AFs. ${ }^{9,16}$

WG contains particularly high levels of glutamine and hydrophobic amino acids (both $\mathrm{ca} .35 \%$ of the total protein). ${ }^{17}$ These types of residues have been associated with AF formation. $^{18,19}$ It has further been suggested that stretching WG proteins in dough systems results in conversion of $\beta$-turns into $\beta$-sheets. ${ }^{20,21}$ It is important to note that WG has both elastic and amyloidogenic properties and that there is a threshold in proline and glycine levels in proteins above which amyloid formation is impeded and elastomeric properties become apparent. ${ }^{18}$ Thus, enriching particular amino acid sequences by proteolysis can result in a tendency of the resultant hydrolysates to form fibrils. Indeed, ALFs are formed by drying WG tryptic hydrolysates on a Teflon-coated aluminum sheet dish at room temperature (RT). ${ }^{22}$ They have a diameter and a length of about 10 and $100 \mu \mathrm{m}$, respectively, as observed with scanning electron microscopy. Fourier transform infrared (FTIR) spectroscopy and X-ray diffraction data suggest that they contain cross $\beta$-sheet structures. $^{22}$ More recently, it has been shown that out of six peptidases, trypsin produces WG hydrolysates that are most successful for producing long (up to $1.3 \mu \mathrm{m}$ ) and straight protein fibrils. ${ }^{2 \frac{3}{3}}$

Efforts have been made to identify the $\beta$-sheet aggregation regions in the fibril backbone. For instance, in contrast to glutenin tryptic hydrolysates, tryptic gliadin hydrolysates form cross $\beta$-sheet structures. ${ }^{22}$ Even more importantly, a highly hydrophobic tryptic gliadin 20 amino acid peptide can act as a template for protein fibril formation. For instance, mixtures of this gliadin peptide and myoglobin (0.36:0.64 $\mathrm{M}$ ratio) result in tape-like protein fibrils after incubation at $37^{\circ} \mathrm{C}$ and $\mathrm{pH} 8.0$ for 20 days. Apparently, this peptide forms stable $\beta$-sheet-rich structures that interact with the $\alpha$-helical sequences in myoglobin and induce $\alpha$-helix to $\beta$-sheet transitions. ${ }^{24,25}$ Moreover, fibrillar structures result from incubating an insoluble glutenin fraction in sodium dodecyl sulfate (SDS) containing medium for up to 105 days at $25{ }^{\circ} \mathrm{C}$ in the presence of either $2.0 \mathrm{M}$ urea or $30 \%(\mathrm{v} / \mathrm{v})$ trifluoroethanol at $\mathrm{pH} 6.0$ to 7.0. ${ }^{26}$ These fibrils also display enhanced thioflavin $\mathrm{T}$ (ThT) fluorescence, which also suggests the presence of $\beta$-sheet structures, but they lack the typical X-ray diffraction pattern for AFs (i.e., 4.7 and $10-11 \AA$ for inter- $\beta$-strand and inter- $\beta$-sheet, respectively). ${ }^{26}$

Even though a considerable number of studies have been conducted on WG fibrillation, AF formation of WG under conditions typical for food processing has not yet been studied. Here, the impact of such heating conditions on WG AF formation was investigated. More particularly, the impact of heating conditions (i.e., $78{ }^{\circ} \mathrm{C}$ for $22 \mathrm{~h}$ or boiling for $15 \mathrm{~min}$ ) that have been reported to successfully induce AF formation in egg white proteins ${ }^{14}$ was investigated. However, the fact that AFs are insoluble in aqueous media and probably entrapped in the WG protein network is an important drawback when studying protein fibril formation. ${ }^{11}$ Therefore, as a follow-up to previous research, ${ }^{14}$ we here evaluated enzymatic treatments with trypsin and/or proteinase $\mathrm{K}$ to isolate protein fibrils based on the principle that they resist enzymatic cleavage better than amorphous aggregates. ${ }^{11,27}$ The morphology of the protein aggregates was studied with transmission electron microscopy (TEM) and their amount with size exclusion high-performance liquid chromatography (SE-HPLC). Fluorescence spectroscopy indicates that these aggregates bind to ThT and are composed of $\beta$-sheet structures as shown by FTIR measurements. Finally, the potential amyloid nature of these protein fibrils was studied with Congo red staining and X-ray 
diffraction measurements. We here report on the outcome of our work.

\section{EXPERIMENTAL SECTION}

Materials. WG containing $75 \%$ protein $(N \times 5.70)$ [determined in triplicate with an automated Dumas protein analysis system (EAS Variomax N/CN, Elt, Gouda, The Netherlands) using an adaptation of the AOAC Official Method 990.03] was obtained from Tereos Starch \& Sweeteners (Aalst, Belgium). Sodium azide was from Acros Organic (Geel, Belgium). SDS and sodium dihydrogen phosphate dihydrate were from VWR International (Leuven, Belgium). Proteinase K (Tritirachium album, P4850), trypsin (porcine pancreas, T0303), and all chemicals (of at least analytical grade) were from Sigma-Aldrich (Bornem, Belgium). Enzyme units (EU) were as specified by the supplier. The highly amylodogenic peptide (residues: 103-112, i.e., NFNYNNNLQG) derived from sup35 yeast was produced in-house. $^{28}$

Heat and Enzymatic Treatments of WG. A quantity of WG $(267 \mathrm{mg})$ containing $200 \mathrm{mg}$ protein in $10.0 \mathrm{~mL} 0.02 \%$ $(\mathrm{w} / \mathrm{v})$ sodium azide was heated at $78^{\circ} \mathrm{C}$ for $22 \mathrm{~h}\left(\mathrm{WG}_{78^{\circ} \mathrm{C} 22 \mathrm{~h}}\right)$ or boiled for $15 \mathrm{~min}\left(\mathrm{WG}_{100^{\circ} \mathrm{C} 15 \mathrm{~min}}\right)$ in sealed conical centrifuge tubes (diameter: $1.7 \mathrm{~cm}$, height: $12 \mathrm{~cm}$ ) in triplicate (see Figure 1). The heated samples were cooled in an icewater bath for at least $5 \mathrm{~min}$. In enzymatic treatment 1 , aliquots of proteinase $\mathrm{K}(32 \mu \mathrm{L}$ containing $c a .26 \mathrm{EU})$, trypsin ( $80 \mu \mathrm{L}$ containing $c a .21$ to $32 \mathrm{k} \mathrm{EU}$ ), or a combination of both were added to samples containing $c a .200 \mathrm{mg}$ unheated and heated protein along with 10 small glass pearls. The samples were incubated at $37{ }^{\circ} \mathrm{C}$ for $48 \mathrm{~h}$ under continuous shaking $(150 \mathrm{rpm})$ and then cooled as indicated above. The supernatants from proteinase $\mathrm{K}$ or trypsin treatments and supernatant fraction 1 ( $\mathrm{SF} 1$ ) resulting from proteinase $\mathrm{K}$ and trypsin treatment (SF 1, see Figure 1) and obtained by centrifugation $\left(5400 \mathrm{~g}, 15 \mathrm{~min}, 20^{\circ} \mathrm{C}\right.$ ) were further analyzed as described later. Pellet 1 of unheated WG, $W_{78^{\circ} \mathrm{C} 22 \mathrm{~h}}$, and $\mathrm{WG}_{100^{\circ} \mathrm{C} 15 \mathrm{~min}}$ (see Figure 1) obtained by proteinase $\mathrm{K}$ and trypsin treatment was dispersed in $8.0 \mathrm{~mL}$ of $0.05 \mathrm{M}$ sodium phosphate buffer (SPB), $\mathrm{pH} 7.0$, for $16 \mathrm{~h}$ at $\mathrm{RT}$ while shaking (150 rpm). SF 2 (see Figure 1) obtained by subsequent centrifugation as mentioned above was analyzed as described later.

In order to purify $\mathrm{WG}_{100^{\circ} \mathrm{C} 15 \mathrm{~min}}$ protein fibrils for Congo red staining and X-ray diffraction analyses, $\mathrm{WG}_{100^{\circ} \mathrm{C} 15 \mathrm{~min}}$ pellet 1 was submitted to a second enzyme treatment (see Figure 2). In this case, $10.0 \mathrm{~mL}$ of $0.02 \%(\mathrm{w} / \mathrm{v})$ sodium azide and proteinase $\mathrm{K}$ and trypsin (as outlined above) were added to the pellet. The resulting samples were incubated for $2 \mathrm{~h}$ at $37^{\circ} \mathrm{C}$ under continuous shaking $(150 \mathrm{rpm})$ (i.e., enzymatic treatment 2 , see Figure 2) and then cooled as indicated above. SF 3 (see Figure 2) obtained by centrifugation as mentioned above was discarded and the resultant $\mathrm{WG}_{100^{\circ} \mathrm{C} 15 \mathrm{~min}}$ pellet 2 was dispersed with SPB and extracted as mentioned above. After centrifugation, SF 4 was removed, the $\mathrm{WG}_{100^{\circ} \mathrm{C} 15 \mathrm{~min}}$ pellet 3 dispersed with $0.02 \%(\mathrm{w} / \mathrm{v})$ sodium azide, and submitted to enzyme treatment with only proteinase $\mathrm{K}$ under the conditions mentioned above (i.e., enzymatic treatment 3, see Figure 2) and then cooled as indicated above. While pellet 4 obtained by centrifugation as mentioned above was discarded, SF 5 was analyzed as described later and concentrated by centrifugation using an Amicon Ultra-0.5 centrifugal filter device $50 \mathrm{~K}$ (Merck, Darmstadt, Germany) as done previously. ${ }^{14}$ The

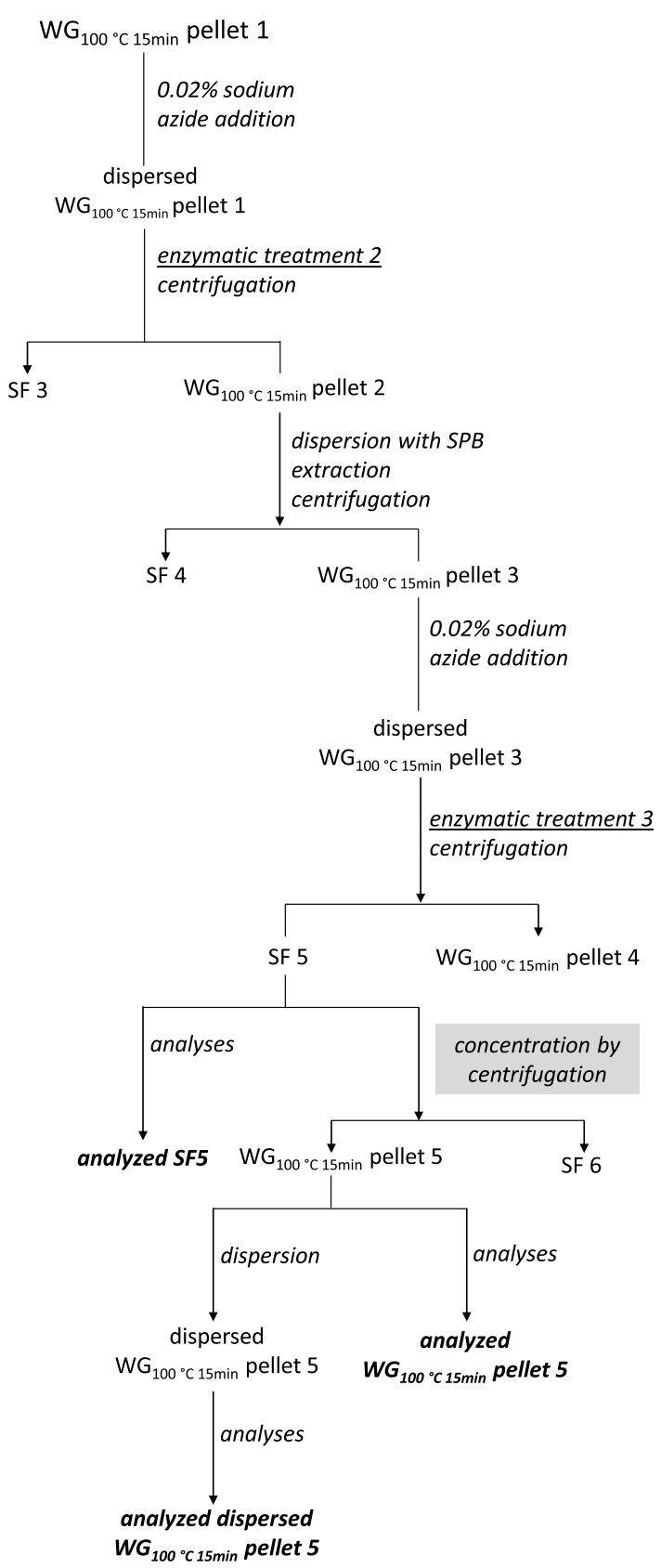

Figure 2. Experimental set-up for enzyme-assisted purification of protein fibrils in pellet 1 of wheat gluten (WG) boiled for $15 \mathrm{~min}$ $\left(\mathrm{WG}_{100^{\circ} \mathrm{C} 15 \mathrm{~min}}\right.$ ) (see Figure 1) as well as for concentration thereof by centrifugation of the resultant fraction. SF $x$ : supernatant fraction $x$, SPB: $0.05 \mathrm{M}$ sodium phosphate buffer ( $\mathrm{pH} 7.0$ ).

concentrated sample was then centrifuged $(10,000 \mathrm{~g}$ for 15 $\mathrm{min}$ ), the resulting SF 6 (Figure 2) was discarded, and the $\mathrm{WG}_{100^{\circ} \mathrm{C} 15 \mathrm{~min}}$ pellet 5 dispersed for TEM analysis or directly used for Congo red staining and X-ray analyses.

Analysis of Protein Content. The percentages of initial WG protein present in SF 1, SF 2, and SF 5 (see Figures 1 and 2) obtained by the different enzymatic treatments were determined in triplicate by measuring the ultraviolet (UV) extinction $(280 \mathrm{~nm})$ in UV-star plates (Greiner Bio-One, Vilvoorde, Belgium) using a Synergy Multi-Mode Microplate Reader (BioTek, Winooski, VT, USA). Absorbance values were converted to protein concentrations using a calibration curve constructed with unheated tryptic WG hydrolyzed to a 

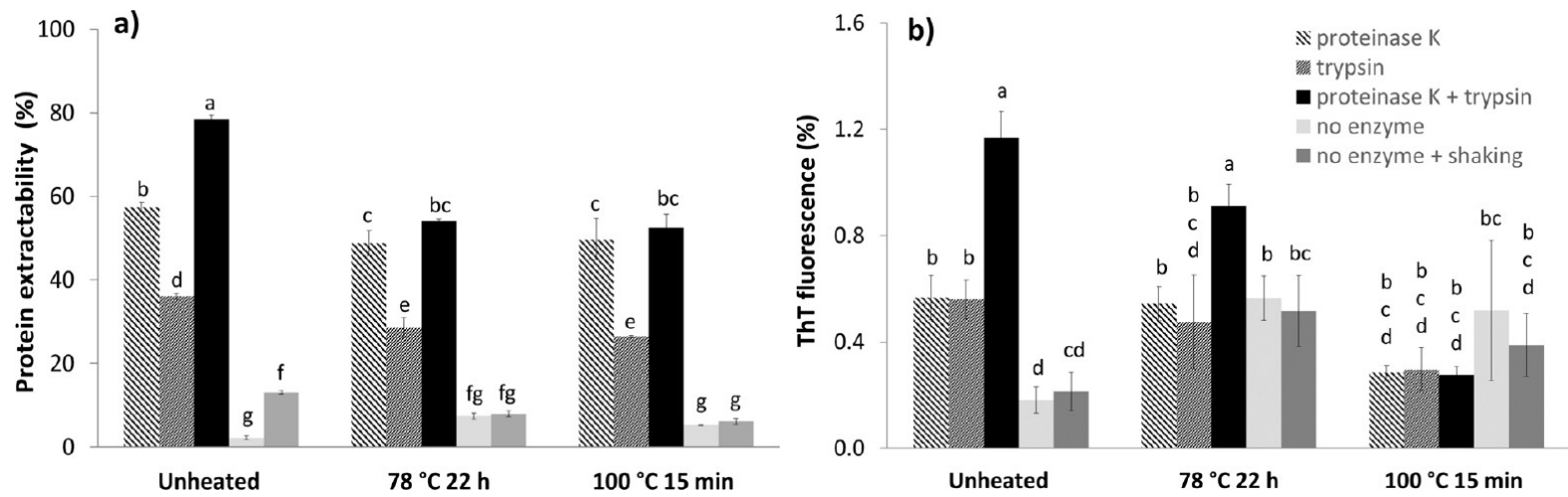

Figure 3. (a) Percentages of total protein recovered in the supernatants after enzyme-assisted extraction with proteinase $\mathrm{K}$, trypsin, or both proteinase $\mathrm{K}$ and trypsin of $2.0 \%\left(\mathrm{w}_{\text {protein }} / \mathrm{v}\right)$ unheated wheat gluten $(\mathrm{WG}), 2.0 \%\left(\mathrm{w}_{\text {protein }} / \mathrm{v}\right) \mathrm{WG}$ heated at $78{ }^{\circ} \mathrm{C}$ for $22 \mathrm{~h}\left(\mathrm{WG}_{78^{\circ} \mathrm{C} 22 \mathrm{~h}}\right)$, or boiled for $15 \mathrm{~min}\left(\mathrm{WG}_{100^{\circ} \mathrm{C} 15 \mathrm{~min}}\right)$ (see Figure 1). (b) Corresponding thioflavin $\mathrm{T}$ (ThT) fluorescence data. Shaking $(150 \mathrm{rpm})$ was $48 \mathrm{~h}$ at $37^{\circ} \mathrm{C}$. Results with the same letters are not significantly different in $P<0.05$. Note that the protein extractability and the ThT fluorescence data for the proteinase $\mathrm{K}$ and trypsin-treated samples are also shown in Figure 5.

degree of hydrolysis of $6(\mathrm{DH} 6)\left(R^{2}=0.9979\right)$. The latter was obtained by hydrolyzing a WG dispersion containing $2.0 \%$ $\left(\mathrm{w}_{\text {protien }} / \mathrm{v}\right)$ at $37^{\circ} \mathrm{C}$ and constant $(\mathrm{pH} \mathrm{8.0)}$ using a Titrino 718 device (Metrohm, Herisau, Switzerland).

Analysis of ThT Fluorescence. ALF formation was monitored with ThT fluorescence measurements in the SF 1, SF 2, and SF 5 samples (see Figures 1 and 2). An enhancement in ThT fluorescence suggests the presence of $\beta$-sheet structures such as the ones present in AFs. ${ }^{29}$ The samples $(190 \mu \mathrm{L})$ were mixed with $10 \mu \mathrm{L}$ of $200 \mu \mathrm{M}$ ThT in a black 96-well plate (Greiner Bio-One), and measured in triplicate in a Synergy Multi-Mode Microplate Reader (BioTek). The excitation and emission wavelengths were 440 and $480 \mathrm{~nm}$, respectively. Extracted protein was diluted to the same protein content $[0.05 \%(\mathrm{w} / \mathrm{v})$ or $0.1 \%(\mathrm{w} / \mathrm{v})]$ with SPB to prevent differences in ThT intensity because of variations in $\mathrm{pH}$ or viscosity. ThT fluorescence is expressed as the fluorescence intensity of the sample relative to that of the above-mentioned sup35 yeast peptide under the applied experimental conditions. ${ }^{28}$

Size Exclusion Chromatography. The apparent molecular weight $(\mathrm{MW})$ distribution of proteins recovered in the SF 2 (see Figure 1) of unheated and heated WG samples was evaluated in triplicate using SE-HPLC. As described before, ${ }^{14}$ ThT was added to the SF2 samples (see Figure 1), which were then filtered. The samples were then loaded on a BioSep-SECS3000 (size range $5-700 \mathrm{kDa}$ for native, $25 \mu \mathrm{L}, 0.5 \mathrm{~mL} \mathrm{SPB} /$ min) column at $30{ }^{\circ} \mathrm{C}$. SE-HPLC was conducted in a Shimadzu (Kyoto, Japan) Prominence modular system with automated injection with both UV (at $280 \mathrm{~nm}$ ) and ThT fluorescence (at 450 and $480 \mathrm{~nm}$ as excitation and emission wavelengths, respectively) detection. ${ }^{14}$ Blue dextran (ca. 2000 $\mathrm{kDa}$ ) was used to determine the void volume of the column, while ovalbumin $(44 \mathrm{kDa})$ and $\alpha$-lactalbumin $(14.4 \mathrm{kDa})$ were used as protein markers.

Transmission Electron Microscopy. The morphology of

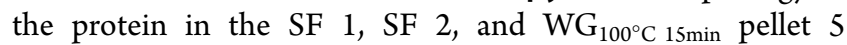
samples (see Figures 1 and 2) was studied with TEM using negative staining with uranyl acetate. Samples (see Figure 1) containing $0.1 \%\left(\mathrm{w}_{\text {protein }} / \mathrm{v}\right)$ were prepared as described previously $^{14}$ and examined using a JEM-1400 TEM (JEOL, Tokyo, Japan) instrument at $80 \mathrm{keV}$. The average length and width of the protein aggregates was determined with ImageJ 1.52a software (National Institutes of Health, Bethesda, MD,
USA) using at least three TEM images and measuring at least 10 different aggregates in the images.

Attenuated Total Reflection FTIR Spectroscopy. The secondary structure of the protein in the SF 1 and SF 2 (see Figure 1) samples $(35 \mu \mathrm{L})$ containing $0.1 \%\left(\mathrm{w}_{\text {protein }} / \mathrm{v}\right.$ ) (see Figure 1) was investigated at least in duplicate with attenuated total reflection FTIR spectroscopy (ATR-FTIR) in a Bruker (Karlsruhe, Germany) Tensor 27 infrared spectrophotometer equipped with a Bio-ATR II (Harrick Scientific Products, Pleasantville, NY, USA) accessory. The instrument was continuously purged with dry air and the spectra were recorded and processed as described before. ${ }^{14}$ Maximum peaks in the amide I area $\left(1600-1700 \mathrm{~cm}^{-1}\right)$ were assigned with peak picking based on the second derivative, as implemented in Bruker OPUS software.

Microscopy of Congo Red Stained Samples. Upon staining with Congo red, AFs exhibit a typical green birefringence. $\mathrm{WG}_{100^{\circ} \mathrm{C} 15 \mathrm{~min}}$ pellet 5 (see Figure 2) was dried on a microscope slide at RT. Next, 7 to $10 \mu \mathrm{L}$ of $0.1 \%(\mathrm{w} / \mathrm{v})$ Congo red was added (RT, $30 \mathrm{~min}$, dark room). The sample was then washed three times with $90 \%(\mathrm{w} / \mathrm{w})$ ethanol prior to being viewed under bright and polarized light with an ECLIPSE 80i epifluorescence microscope (Nikon, Melville, NY, USA) equipped with a Nikon Digital Sight DS-US camera and Nikon NIS-Elements Viewer 4.0 software.

X-ray Diffraction Analysis. The repetitive crystalline structure of AFs along the fibril axis was studied with X-ray diffraction. $\mathrm{WG}_{100^{\circ} \mathrm{C}} 15 \mathrm{~min}$ pellet 5 (see Figure 2) was dried between two wax-tipped capillary tubes. Diffraction patterns were collected as done previously, ${ }^{14}$ analyzed using Adxv software (Scripps Research, La Joya, CA, USA), and displayed with an iMosFLM. ${ }^{30}$

Statistical Analysis. Significant differences $(\alpha<0.05)$ based on at least three individual measurements were determined with a one-way ANOVA procedure using JMP Pro 14.0.0 (SAS Institute, Cary, NC, USA). The corresponding Tukey's grouping coefficients are given.

\section{RESULTS AND DISCUSSION}

Protein Extracted by Different Enzymatic Treatments from Unheated and Heated WG Dispersions. The lack of solubility of WG in aqueous media and further protein aggregation during heating hampered the identification and characterization of the proteins present. We here evaluated the 

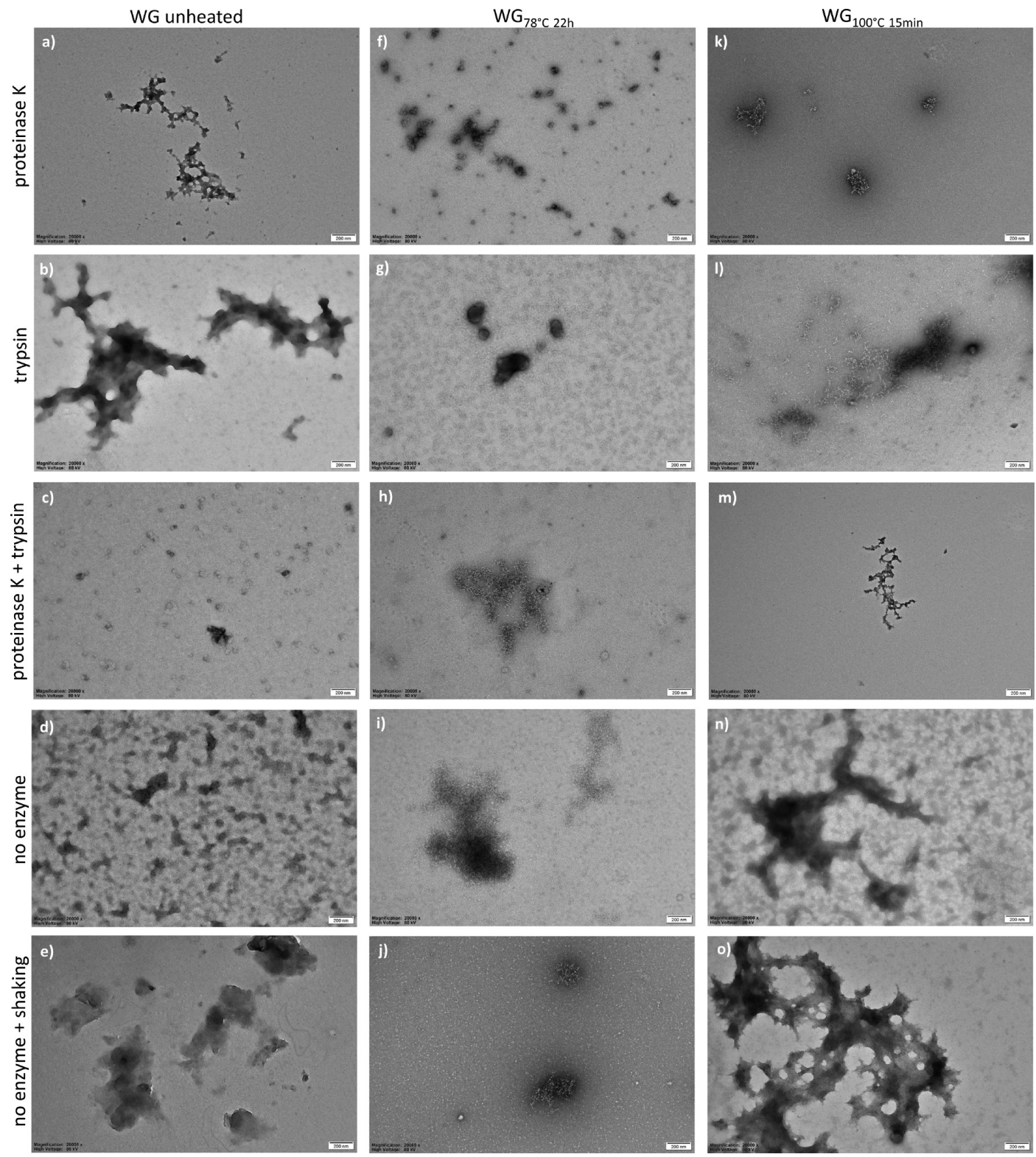

Figure 4. Transmission electron microscopy (TEM) of the materials in the supernatants obtained after enzymatic treatment (see Figure 1) of unheated wheat gluten (WG, a-e), WG heated at $78^{\circ} \mathrm{C}$ for $22 \mathrm{~h}\left(\mathrm{WG}_{78^{\circ} \mathrm{C} 22 \mathrm{~h}} \mathrm{f}-\mathrm{j}\right)$, or boiled for $15 \mathrm{~min}\left(\mathrm{WG}_{100^{\circ} \mathrm{C} 15 \mathrm{~min}}, \mathrm{k}-\mathrm{o}\right)$. Shaking $(150 \mathrm{rpm})$ was $48 \mathrm{~h}$ at $37^{\circ} \mathrm{C}$. Scale bar: $200 \mathrm{~nm}$.

impact of different enzymatic treatments on the extraction of proteins from unheated and heated WG. Moreover, the addition of limited amounts of enzymes may result in hydrolysis of amorphous proteins rather than that of AFs and thus in concentration of the latter. ${ }^{11,27}$ First, proteinase $\mathrm{K}$ treatment of $\mathrm{WG}_{78^{\circ} \mathrm{C} 22 \mathrm{~h}}$ and $\mathrm{WG}_{100^{\circ} \mathrm{C} 15 \mathrm{~min}}$ resulted in a similar protein extractability (ca. 50\%) (see Figure 3a). When unheated WG was treated the same way, a slightly higher protein extractability was noted. In all three instances, the solubilized material had low ThT fluorescence $(<0.6 \%)$ (see Figure $3 \mathrm{~b})$. Nonetheless, the FTIR spectra of the supernatant resulting from treating unheated $W G$ and $W G_{78^{\circ} \mathrm{C} 22 \mathrm{~h}}$ with proteinase $\mathrm{K}$ showed characteristic wavenumbers of $\beta$-sheets in both the $1696 \pm 2.0$ to $1667 \pm 1.0$ and the $1642 \pm 1.0$ to 1624 $\pm 1.0 \mathrm{~cm}^{-1}$ regions, ${ }^{31}$ but only in the latter one for $\mathrm{WG}_{100^{\circ} \mathrm{C}}$ 15 min (see Figure S1). Last, TEM images revealed the presence of mainly amorphous aggregates after treating unheated and heated WG with proteinase K (see Figure 4a,f,k).

Second, a trypsin treatment was applied. Trypsin selectively cleaves after lysine and arginine residues, which are generally not present in aggregation prone regions, and can result in intact aggregation prone regions. ${ }^{11}$ Tryptic treatment of unheated and heated WG resulted in significantly lower protein extractabilities (ca. $30 \%$ ) than did proteinase $\mathrm{K}$ (see Figure 3a). However, the ThT fluorescence values of the material solubilized from unheated $W G, W_{78^{\circ} \mathrm{C} 22 \mathrm{~h}}$, and $\mathrm{WG}_{100^{\circ} \mathrm{C} 15 \mathrm{~min}}$ with trypsin were similar to those of the material solubilized with proteinase $\mathrm{K}$ (see Figure $5 \mathrm{~b}$ ). While the FTIR

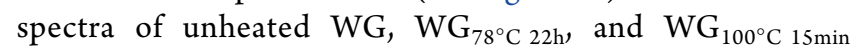
material, which had been solubilized by trypsin treatment, showed $\beta$-sheet characteristic wavenumbers (see Figure $\mathrm{S} 1$ ), mainly amorphous protein aggregates were observed with TEM (see Figure 4b,g,l, respectively). Nonetheless, the tryptic 

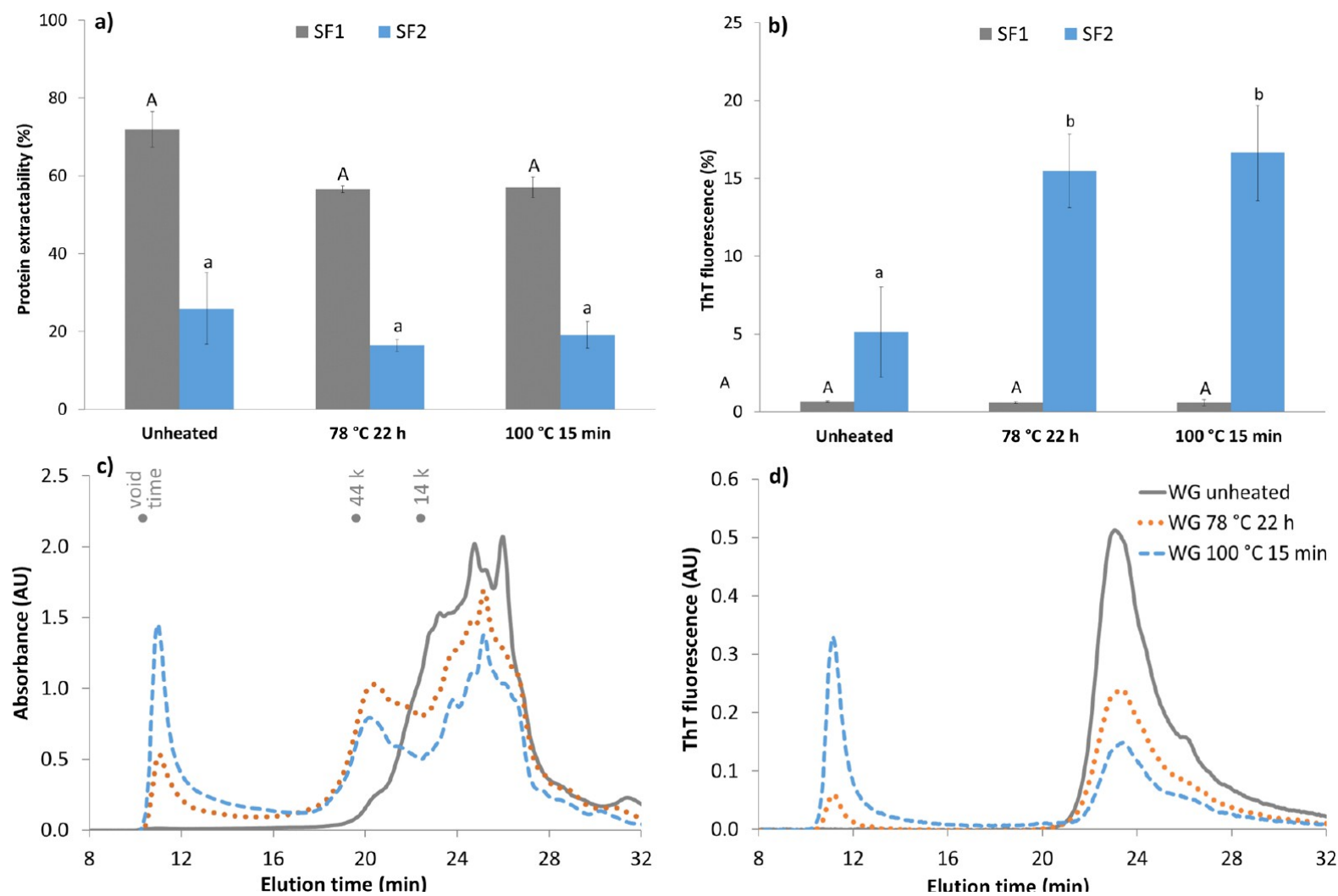

Figure 5. (a) Percentages of total protein recovered in (i) supernatant fraction 1 (SF 1, see Figure 1) after extraction with proteinase $\mathrm{K}$ and trypsin treatment from unheated wheat gluten (WG), WG heated at $78{ }^{\circ} \mathrm{C}$ for $22 \mathrm{~h}\left(\mathrm{WG}_{78^{\circ} \mathrm{C} 22 \mathrm{~h}}\right)$, or boiled for 15 min $\left(\mathrm{WG}_{100^{\circ} \mathrm{C} 15 \mathrm{~min}}\right)$ and (ii) SF 2 (see Figure 1) after extraction with $0.05 \mathrm{M} \mathrm{SPB}(\mathrm{pH} 7.0)$. (b) Corresponding thioflavin T (ThT) fluorescence data. Results with the same letters are not significantly different $(P<0.05)$ for the SF 1 (uppercase) and SF 2 (lowercase) samples. Size exclusion high performance liquid chromatography (SE-HPLC) profiles showing (c) UV absorbance and (d) ThT fluorescence of the above SF 2 samples. Molecular weight (MW) markers are indicated at the top of the SE-HPLC profiles (blue dextran, void volume; 44k, ovalbumin; $14 \mathrm{k}, \alpha$-lactalbumin). AU, arbitrary units.

extracts of $\mathrm{WG}_{100^{\circ} \mathrm{C} 15 \mathrm{~min}}$ contained some worm-like protein structures (see Figure 41).

Third, the impact of a combined proteinase $\mathrm{K}$ and trypsin treatment was studied. Higher protein extractability (ca. 80\%) and ThT fluorescence (ca. 1.2\%) (see Figure 3a,b) were obtained in the SF 1 from unheated WG than from $W_{78^{\circ} \mathrm{C} 22 \mathrm{~h}}$ and $\mathrm{WG}_{100^{\circ} \mathrm{C} 15 \mathrm{~min}}$ (see Figure 1). However, the FTIR spectra of protein recovered in the SF 1 of unheated WG did not show wavenumbers in both characteristic $\beta$-sheet regions (see Figure S1) and mainly amorphous aggregates were observed with TEM (see Figure 4c). While the protein extractability (ca. $60 \%$ ) of SF 1 of $\mathrm{WG}_{78^{\circ} \mathrm{C} 22 \mathrm{~h}}$ and $\mathrm{WG}_{100^{\circ} \mathrm{C} 15 \mathrm{~min}}$ was similar to those after only proteinase $\mathrm{K}$ treatment (see Figure $3 \mathrm{a}$ ), the ThT fluorescence of the SF 1 of $\mathrm{WG}_{78^{\circ} \mathrm{C} 22 \mathrm{~h}}$ (ca. $\left.0.9 \%\right)$ was slightly higher than that of the SF 1 of $\mathrm{WG}_{100^{\circ} \mathrm{C}} 15 \min (\mathrm{ca} .0 .3 \%)$ (see Figure $3 \mathrm{~b}$ ). The presence of $\beta$-sheet structures in the SF 1 of $\mathrm{WG}_{78^{\circ} \mathrm{C} 22 \mathrm{~h}}$ and $\mathrm{WG}_{100^{\circ} \mathrm{C} 15 \mathrm{~min}}$ (see Figure S1) was also confirmed with FTIR. Nevertheless, TEM images show mainly amorphous aggregates with some worm-like protein fibrils in both extracts (see Figures $4 \mathrm{~h}$ and $6 \mathrm{~m}$, respectively).

In general, proteinase $\mathrm{K}$ and trypsin treatment solubilized more (unheated WG) or similar $\left(W^{\circ} G_{78^{\circ} \mathrm{C} 22 \mathrm{~h}}\right.$ and $\mathrm{WG}_{100^{\circ} \mathrm{C} 15 \mathrm{~min}}$ ) protein amounts than when these enzymes were used separately. ThT fluorescence of protein recovered in the SF1 of unheated WG and $\mathrm{WG}_{78^{\circ} \mathrm{C} 22 \mathrm{~h}}$ treated with both enzymes was higher than that resulting from solely proteinase $\mathrm{K}$ and trypsin treatment. In contrast, the ThT fluorescence in the SF 1 of $\mathrm{WG}_{100^{\circ} \mathrm{C} 15 \mathrm{~min}}$ was similar irrespective of whether one of the enzymes had been used. These results lend support to the hypothesis that a combined proteinase $\mathrm{K}$ and trypsin treatment solubilizes more amorphous structures than each of the single peptidases does alone, as observed previously during the isolation of AFs from boiled egg white. ${ }^{14}$ As hardly any fibrillar material was solubilized, the isolated protein fibrils may have been recovered in the resultant pellet 1 (see Figure 1).

The fact that protein fibrils can be formed during shaking (150 rpm) of ovalbumin solutions at $37{ }^{\circ} \mathrm{C}^{14}$ prompted us to evaluate the impact of shaking without enzyme addition on protein fibril formation of unheated $W G, W_{78^{\circ} \mathrm{C} 22 \mathrm{~b}}$ and

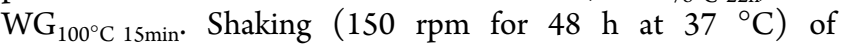
unheated WG caused an increment in its protein extractability (ca. 13\%) in comparison with unshaken unheated WG (ca. $2 \%$ ) (see Figure 3a). This is probably related to the presence of endogenous enzymes in $\mathrm{WG}^{32}$ which became active in aqueous media, and promoted WG solubilization. ${ }^{33}$ Nonetheless, ThT fluorescence of unheated WG dispersions was negligible irrespective of whether the sample had been shaken (see Figure $3 \mathrm{~b}$ ). The FTIR spectra of protein recovered after shaking and centrifugation of unheated WG showed a stronger peak ascribed to $\alpha$-helix structure (i.e., $1651 \mathrm{~cm}^{-1}$ ) compared to that of unheated WG that had not been shaken (see Figure S2a), although both unheated WG samples mainly contained amorphous aggregates as visualized with TEM (see Figure $4 d, e)$.

The protein extractability (ca. 7 and 5\%, respectively) and the ThT fluorescence (ca. 0.5 and $0.4 \%$, respectively) of shaken 

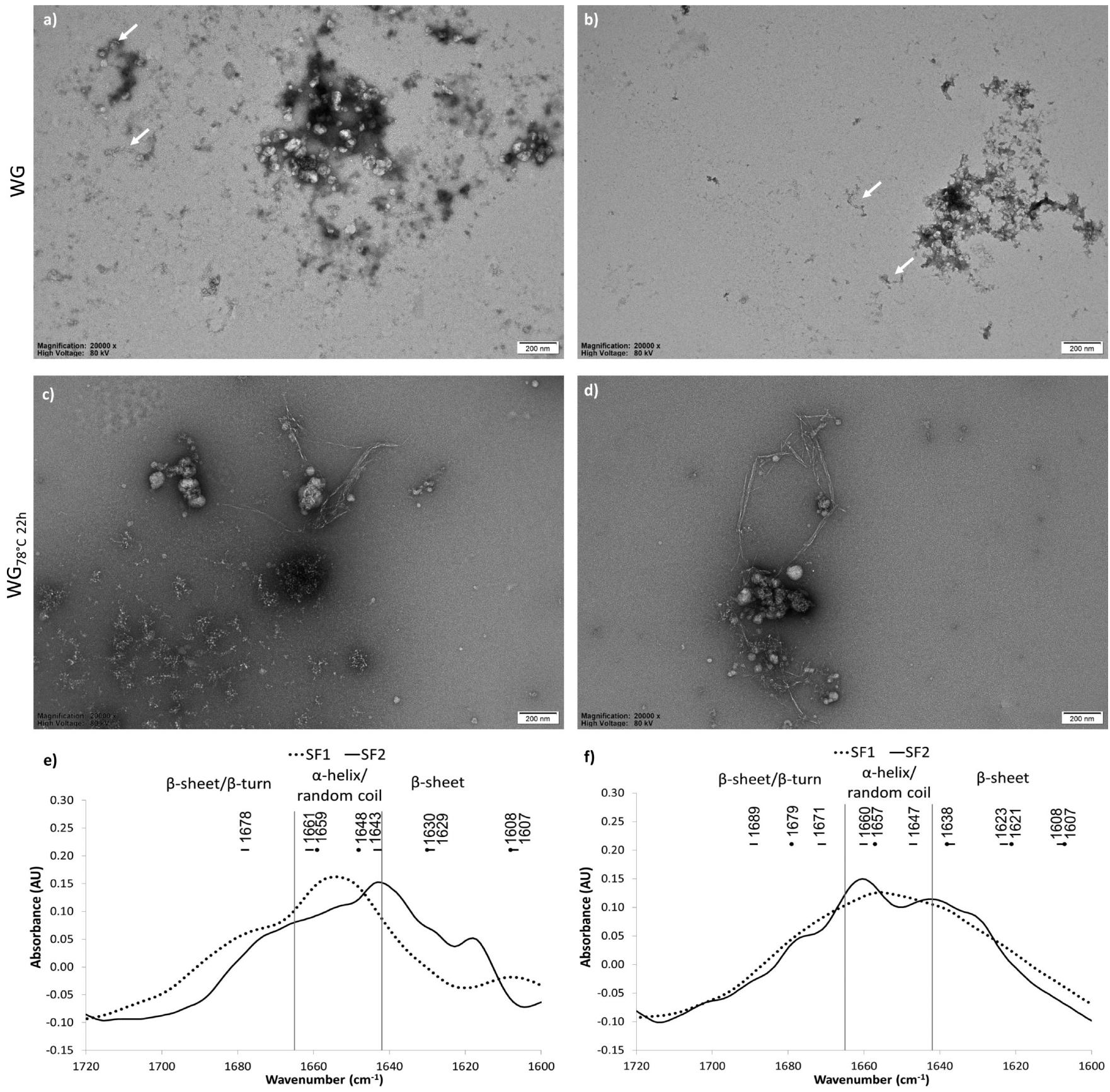

Figure 6. Protein fibrils in unheated wheat gluten (WG) and WG heated at $78{ }^{\circ} \mathrm{C}$ for $22 \mathrm{~h}\left(\mathrm{WG}_{78^{\circ} \mathrm{C} 22 \mathrm{~h}}\right)$. Transmission electron microscopy (TEM) images of supernatant fraction 2 (SF 2, see Figure 1) from unheated WG (a and b) and $W G_{78^{\circ} \mathrm{C} 22 \mathrm{~h}}(\mathrm{c}, \mathrm{d})$ ). Arrows in $(\mathrm{a}, \mathrm{b})$ show protein fibrils. Scale bar: $200 \mathrm{~nm}$. Fourier transform infrared (FTIR) spectra of the SF 1 and SF 2 samples (see Figure 1) from unheated WG (e) and WG $\mathrm{W}_{78^{\circ} \mathrm{C} 22 \mathrm{~h}}(\mathrm{f})$. Wavenumbers in $(e, f)$ are determined with the peak picking tool based on the second derivative. Vertical lines in (e,f) separate the wavenumbers assigned to the secondary structure of proteins. AU, arbitrary units.

and centrifuged $\mathrm{WG}_{78^{\circ} \mathrm{C} 22 \mathrm{~h}}$ and $\mathrm{WG}_{100^{\circ} \mathrm{C} 15 \mathrm{~min}}$ were comparable to those of their unshaken counterparts and are thus negligible (see Figure 3a,b). While the FTIR spectra of protein recovered after shaking and centrifugation of $\mathrm{WG}_{78^{\circ} \mathrm{C} 22 \mathrm{~h}}$ were slightly shifted to lower wavenumbers in comparison to those of unshaken $\mathrm{WG}_{78^{\circ} \mathrm{C} 22 \mathrm{~h}}$ (see Figure S2b), the FTIR spectra of protein resulting from unshaken and shaken $\mathrm{WG}_{100^{\circ} \mathrm{C} 15 \mathrm{~min}}$ protein samples were similar (see Figure S2c). TEM images showed the presence of mainly amorphous aggregates in the soluble fractions irrespective of whether $\mathrm{WG}_{78^{\circ} \mathrm{C} 22 \mathrm{~h}}$ (see Figure $4 \mathrm{i}, \mathrm{j}$, respectively) and $\mathrm{WG}_{100^{\circ} \mathrm{C} 15 \mathrm{~min}}$ (see Figure $4 \mathrm{n}, \mathrm{o}$, respectively) had been shaken. These results indicate that shaking at $150 \mathrm{rpm}$ for $48 \mathrm{~h}$ at $37{ }^{\circ} \mathrm{C}$ did not result in the formation of soluble protein fibrils in unheated and heated WG and that the differences in protein fibril extractability were related to the action of the endogenous peptidases present.

Last, we consider that the impact of peptidase addition on WG fibril formation was limited under our experimental conditions as proteinase $\mathrm{K}$ and trypsin were added in limited amounts (enzyme preparation to substrate ratio, 1:625, 1:125, respectively). In addition, interactions between aggregation prone regions may have been restricted by the presence of 

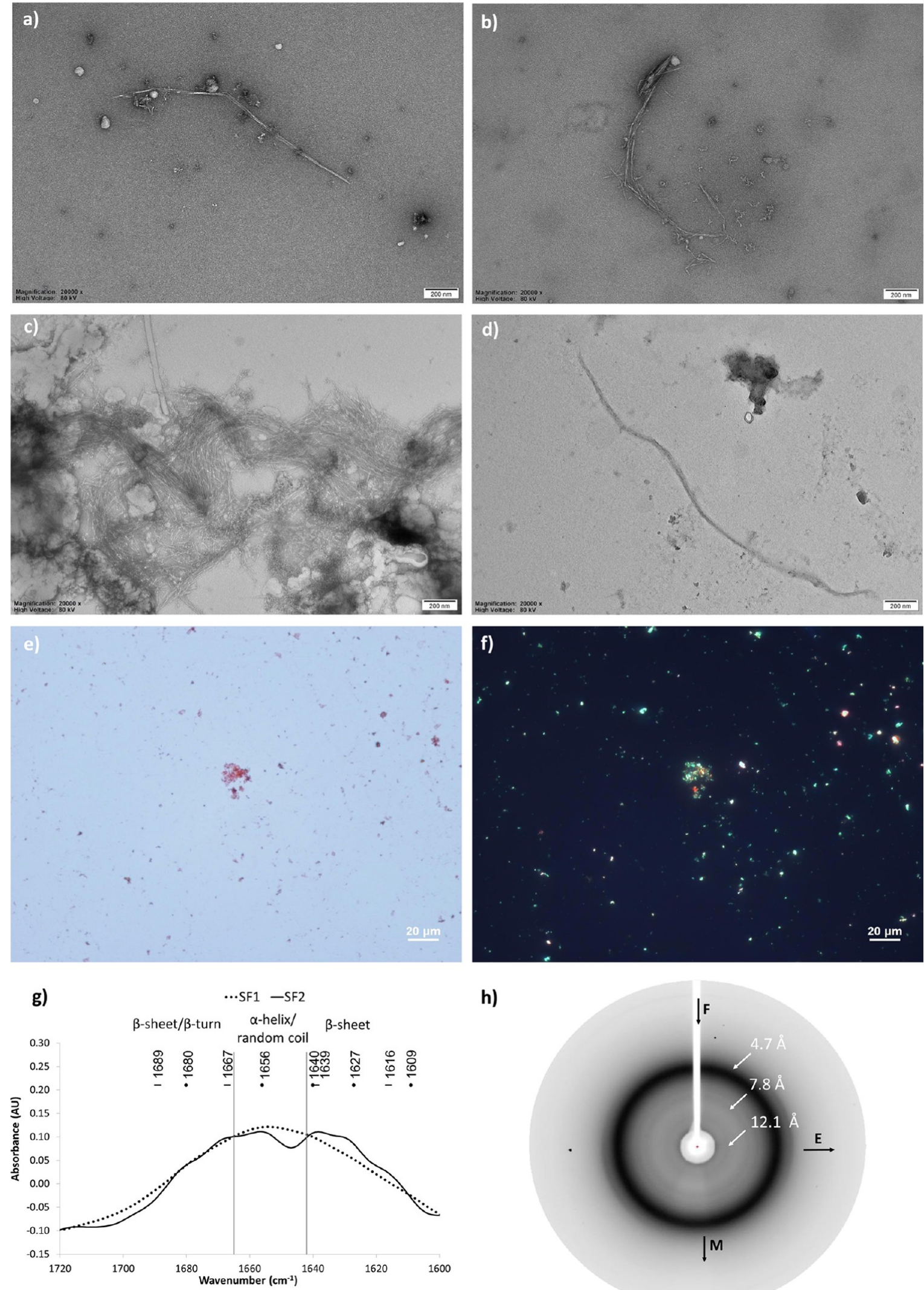

h)

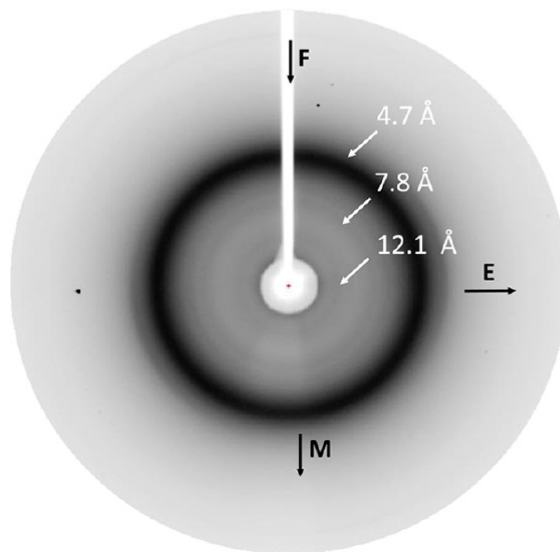

Figure 7. Amyloid-like fibrils (ALFs) in wheat gluten (WG) boiled for $15 \mathrm{~min}\left(\mathrm{WG}_{100^{\circ} \mathrm{C} 15 \mathrm{~min}}\right)$. Transmission electron microscopy (TEM) images (a,b,c,d, respectively, scale bar: $200 \mathrm{~nm}$ ) of the supernatant fraction 2 (SF 2, see Figure 1) and of the dispersed $\mathrm{WG}_{100^{\circ} \mathrm{C}} 15 \mathrm{~min}$ pellet 5 (see Figure 2). Congo red stained sample of the $\mathrm{WG}_{100^{\circ} \mathrm{C} 15 \mathrm{~min}}$ pellet 5 (see Figure 2) observed under bright light (e) and under cross-polar light (f) (scale bar: $20 \mu \mathrm{m}$ ). Fourier transform infrared (FTIR) spectra $(\mathrm{g})$ of $\mathrm{WG}_{100^{\circ} \mathrm{C} 15 \mathrm{~min}}$. SF 1 and SF 2 (see Figure 1). Wavenumbers in $(\mathrm{g})$ are determined with the peak picking tool based on the second derivative. Vertical lines in $(\mathrm{g})$ separate the wavenumbers assigned to the secondary structure of proteins. $\mathrm{AU}$, arbitrary units. X-ray diffraction pattern $(\mathrm{h})$ of the aligned fibers prepared from the $\mathrm{WG}_{100^{\circ} \mathrm{C}} 15 \min$ pellet 5 (see Figure 2). 
more soluble amorphous proteins, considering that peptidases generally hydrolyze amorphous proteins rather than AFs. ${ }^{11}$ Nonetheless, it would be useful to evaluate shorter incubation times.

Protein Fibrils Extracted from Unheated and Heated WG Dispersions by Proteinase $\mathrm{K}$ and Trypsin. The presence of protein fibrils in the pellets isolated after proteinase $\mathrm{K}$ and trypsin treatment of unheated and heated WG was further investigated. As outlined above, we hypothesized that protein fibrils may have precipitated in the resultant pellet 1 obtained after proteinase $\mathrm{K}$ and trypsin treatment of unheated and heated WG (see Figure 1). Indeed, less but ThT-positive protein was present in the SF 2 of unheated and heated WG than in its respective SF 1 (see Figure 5a,b).

Although higher levels of protein were present in the SF 2 (see Figure 1) of unheated WG (ca. 25\%) than in those of either $\mathrm{WG}_{78^{\circ} \mathrm{C} 22 \mathrm{~h}}$ or $\mathrm{WG}_{100^{\circ} \mathrm{C} 15 \min }(\mathrm{ca} .16 \%)$ (see Figure $3 \mathrm{a}$ ), the ThT fluorescence was lower (ca. 5\%) in the SF 2 of unheated WG than in those of the heated samples (ca. 16\%) (see Figure 5a,b). In addition, the SE-HPLC profiles of the SF 2 of $\mathrm{WG}_{100^{\circ} \mathrm{C} 15 \mathrm{~min}}$ showed higher levels of larger proteins (elution time ca. 10-12 $\mathrm{min}$ ) than did those of both $\mathrm{WG}_{78^{\circ} \mathrm{C} 22 \mathrm{~h}}$ and unheated WG (Figure 5c). These aggregates are indeed very large as their elution pattern overlaps with the void volume as shown in Figure 5c. Importantly, these large $\mathrm{WG}_{100^{\circ} \mathrm{C} 15 \mathrm{~min}}$ protein aggregates had higher ThT fluorescence than those of unheated $W G$ and $W^{-} G_{78^{\circ} \mathrm{C} 22 \mathrm{~h}}$ (see Figure $5 \mathrm{c}, \mathrm{d}$ ).

In addition, the SF 2 of unheated WG contained smaller proteins (elution time ca. 20-28 min, apparent MW below $44 \mathrm{k}$ ) with high $\mathrm{ThT}$ fluorescence, whereas those from $\mathrm{WG}_{78^{\circ} \mathrm{C} 22 \mathrm{~h}}$ or $\mathrm{WG}_{100^{\circ} \mathrm{C} 15 \mathrm{~min}}$ also contained protein fragments of similar size but with lower ThT fluorescence (see Figure $5 c, d)$. Thus, heating also reduced the presence of small protein fragments with enhanced ThT fluorescence in WG by possibly promoting their assembly into large $\beta$-sheet-rich protein aggregates. Fluorescence density measurements, that is, the area of ThT fluorescence relative to that of UV absorbance, showed a higher propensity of amyloid-like aggregation in heated than in unheated WG as observed in Figure 5b.

TEM images of protein recovered in the SF 2 of unheated WG (see Figure 1) revealed the presence of mainly amorphous aggregates in combination with some small (ca. 100-200 nm in length) protein fibrils (see Figure 6a,b). The FTIR spectra of protein in the SF2 were shifted (see Figure 6e) to lower wavenumbers in comparison to those of protein in the SF 1 (see Figure 1), which suggests an increase in ordered secondary protein structures in the SF 2 of unheated WG. These results indicate that commercial WG already contains some protein fibrils, presumably as a result of being dried industrially. ${ }^{3}$ Previously, the presence of ALFs as a result of the drying process of hen egg white was described. ${ }^{15}$

In contrast, the SF 2 of $\mathrm{WG}_{78^{\circ} \mathrm{C} 22 \mathrm{~h}}$ (see Figure $6 \mathrm{c}, \mathrm{d}$ ) contained longer and more straight (ca. $700 \mathrm{~nm}$ in length) protein fibrils than that of unheated WG but shorter than those in the SF 2 of $W_{100^{\circ} \mathrm{C} 15 \text { min }}$ (see Figure $7 \mathrm{a}, \mathrm{b}$ ). In addition, the FTIR spectra of protein in the SF 2 of both $W_{78^{\circ} \mathrm{C} 22 \mathrm{~h}}$ and $\mathrm{WG}_{100^{\circ} \mathrm{C} 15 \mathrm{~min}}$ (see Figures $6 \mathrm{f}$ and $7 \mathrm{~g}$, respectively) indicated the presence of $\beta$-sheet structures. Indeed, the FTIR spectra of both $\mathrm{WG}_{78^{\circ} \mathrm{C} 22 \mathrm{~h}}$ and $\mathrm{WG}_{100^{\circ} \mathrm{C} 15 \mathrm{~min}}$ protein recovered in their SF 2 showed wavenumber characteristic of $\beta$-sheets in AFs (ca. 1630 and $\left.1611 \mathrm{~cm}^{-1}\right){ }^{34}$ Therefore, heating conditions that resemble slow cooking induced protein fibrils in WG but to a smaller extent than did boiling, and thus, further characterization was performed for the latter ones.

Amyloid-like Fibrils (ALFs) in Boiled WG Dispersions. AFs have a characteristic fibrillar morphology. They share a common cross $\beta$-sheet structure and the ability to bind Congo red, which results in a typical apple green birefringence when viewed under cross polarizers in a light microscope. ${ }^{9,16}$ In this study, ALFs were recovered in the SF 2 of $\mathrm{WG}_{100^{\circ} \mathrm{C} 15 \mathrm{~min}}$ (see Figure 1). The fibrils were straight, long ( $c a .1-2 \mu \mathrm{m}$ in length), and unbranched (see Figures $7 \mathrm{a}, \mathrm{b}$ and S3), with fibril diameters of approximately $90 \AA$, consistent with typical widths of AFs. ${ }^{35}$ Although similar levels of ThT fluorescence (ca. 17\%, see Figure $7 \mathrm{~b}$ ) were observed for boiled egg white (ca. 20\%), the latter contained predominantly short $(<c a .120 \mathrm{~nm}$ in length) and worm-like AFs. ${ }^{14}$ In addition, the FTIR spectra of protein in the SF 2 of $\mathrm{WG}_{100^{\circ} \mathrm{C} 15 \mathrm{~min}}$ (see Figure 1) were shifted to lower wavenumbers in comparison to those of its SF 1 (see Figure $7 \mathrm{~g}$ ). This indicated a higher level of ordered protein structures. Of further importance is that the lower maximum amide I absorbance (i.e., $1616 \mathrm{~cm}^{-1}$ ) suggested the presence of $\beta$-sheets in AFs. ${ }^{34}$

Protein fibrils in $\mathrm{WG}_{100}{ }^{\circ} \mathrm{C} 15 \min$ pellet 5 (see Figures $7 \mathrm{c}, \mathrm{d}$ and S3) also displayed the typical amyloid green birefringence when stained with Congo red (see Figures 7e,f and S3). The Xray diffraction pattern of oriented fibers from the $\mathrm{WG}_{100^{\circ} \mathrm{C} 15 \mathrm{~min}}$ pellet 5 sample also showed a strong reflection at $4.7 \AA$, which is characteristic of the intermolecular $\beta$-strand distance. Two weaker additional reflections were observed at 7.8 and $12.1 \AA$, respectively (see Figure $7 \mathrm{~h}$ ). The latter most probably indicates the distance between packed $\beta$-sheets. In previous studies, equatorial reflections at 12.9 and $15.4 \AA$ have been noted for glutenin ${ }^{26}$ and $\mathrm{WG}^{22}$ fibers, respectively. In addition, it has been proposed that glutamine-rich peptides such as the ones present in WG can be organized in alternative inter- $\beta$ sheet through additional hydrogen bonding via amino acid side chains. ${ }^{36}$ However, because of poor orientation of the fibers, the reflections appeared as rings. Thus, the typical orientation of a cross- $\beta$ diffraction pattern was absent. This lack of orientation was observed for three independent preparations and may have been due to the fact that the samples still contained amorphous structures (see Figure 7c). Similar $d$ values have been reported using wide-angle X-ray scattering measurements and ascribed to $\alpha$-helical inter-distances of gluten proteins. ${ }^{37}$ Nonetheless, based on our FTIR spectra compatible with cross- $\beta$-conformation for protein in $\mathrm{WG}_{100^{\circ} \mathrm{C} 15 \mathrm{~min}}$ SF 2 (see Figure $7 \mathrm{~g}$ ), it is more probable that these reflections can be attributed to packed $\beta$-sheets of AFs formed by polyglutamine-rich sequences. ${ }^{36}$

Boiling WG for $15 \mathrm{~min}$ caused approximately $0.1-0.5 \%$ of WG protein to be present as ALFs in the SF 2. This level was calculated from the quantity of protein in the high ThT fluorescence regions of the SE-HPLC profile (see Figure 3c) relative to that of the total WG protein in the SE-HPLC profile when solubilized in $0.05 \mathrm{M} \mathrm{SPB}(\mathrm{pH} 6.8)$ containing $2.0 \%$ SDS and $1.0 \%(\mathrm{w} / \mathrm{v})$ dithiothreitol. ${ }^{38}$ The here reported observation that ALFs or even maybe AFs are formed by boiling WG are totally novel and complement the recent reports of the potential of food processing conditions to induce fibrillation of amyloid nature in food proteins.

\section{CONCLUSIONS}

Although commercial WG already contains some protein fibrils probably as a result of drying during its industrial isolation, the 
level of protein fibrils increases by boiling and conditions similar to those of slow cooking. In this study, protein fibrils from unheated and heated WG were purified with proteinase $\mathrm{K}$ and trypsin treatment. From the pellet obtained after proteinase $\mathrm{K}$ and trypsin treatment of boiled WG, long ( $c a$. $1-2 \mu \mathrm{m}$ in length) and straight ALFs were extracted with SPB. Although FTIR and Congo red staining pointed toward the presence of AFs, the lack of the typical orientation of cross- $\beta$ patterns did not allow designating these WG fibrils as true AFs. Nonetheless, these results show for the first time the presence of ALFs in WG heated under conditions relevant for food processing. Considering previous research which demonstrated the presence of AFs in boiled hen egg white, ${ }^{14}$ this is the second report that heating under food processing relevant conditions impact protein fibrillation by producing ALFs and even AFs. In addition, these results also highlight the potential of enzymatic extraction as a useful tool to study amyloids in food complex matrices. The presence and potential role of these structures in food products should be further investigated, as they may be exploitable to the benefit of food quality. For instance, food protein fibril formation may be tailored for applications wherein foaming, emulsifying, and/or gelling properties determine the overall food product quality. Enhancing plant protein functionality, such as that of WG, can drastically increase their usage in food systems. For this, more fundamental understanding of specific protein regions involved in the fibrillation process, the impact of other food constituents on this process, and functional characterization of the resultant protein fibrils are needed.

\section{ASSOCIATED CONTENT}

\section{S) Supporting Information}

The Supporting Information is available free of charge at https://pubs.acs.org/doi/10.1021/acsomega.0c03670.

Morphology and birefringence with Congo red dye of amyloid-like protein fibrils in $\mathrm{WG}_{100}{ }^{\circ} \mathrm{C} 15 \mathrm{~min}$; FTIR spectra of protein extracted by proteinase $\mathrm{K}$, trypsin, or both proteinase $\mathrm{K}$ in the supernatants of unheated $\mathrm{WG}, \mathrm{WG}_{78^{\circ} \mathrm{C} 22 \mathrm{~h}}$, and $\mathrm{WG}_{100^{\circ} \mathrm{C} 15 \mathrm{~min}}(\mathrm{PDF})$

\section{AUTHOR INFORMATION}

\section{Corresponding Author}

Margarita Monge-Morera - Laboratory of Food Chemistry and Biochemistry and Leuven Food Science and Nutrition Research Centre (LFoRCe), KU Leuven, B-3001 Leuven, Belgium; 이이이.org/0000-0002-3682-2095; Phone: +32 16 329082; Email: margarita.mongemorera@kuleuven.be; Fax: +32 16321997

\section{Authors}

Marlies A. Lambrecht - Laboratory of Food Chemistry and Biochemistry and Leuven Food Science and Nutrition Research Centre (LFoRCe), KU Leuven, B-3001 Leuven, Belgium; (1) orcid.org/0000-0002-3276-6540

Lomme J. Deleu - Laboratory of Food Chemistry and Biochemistry and Leuven Food Science and Nutrition Research Centre (LFoRCe), KU Leuven, B-3001 Leuven,

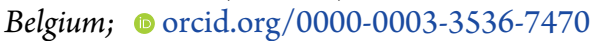

Nikolaos N. Louros - Switch Laboratory, Department of Cellular and Molecular Medicine, KU Leuven, B-3001 Leuven, Belgium; 이이.org/0000-0002-4030-1022
Frederic Rousseau - Switch Laboratory, Department of Cellular and Molecular Medicine, KU Leuven, B-3001 Leuven, Belgium

Joost Schymkowitz - Switch Laboratory, Department of Cellular and Molecular Medicine, KU Leuven, B-3001 Leuven, Belgium

Jan A. Delcour - Laboratory of Food Chemistry and Biochemistry and Leuven Food Science and Nutrition Research Centre (LFoRCe), KU Leuven, B-3001 Leuven, Belgium

Complete contact information is available at:

https://pubs.acs.org/10.1021/acsomega.0c03670

\section{Notes}

The authors declare no competing financial interest.

\section{ACKNOWLEDGMENTS}

The Research Foundation-Flanders (FWO) is thanked for SBO grant S003918N and postdoctoral mandate grant 12 V6718N of M. A. Lambrecht. The Switch Laboratory was supported by ERC Grant agreement 647458 (MANGO) to J. Schymkowitz, the Flanders Institute for Biotechnology (VIB), the KU Leuven, the FWO-Flanders, IWT (SBO grant 60839), and Belspo (IUAP grant P7/16). L. Liesenborghs is acknowledged for excellent technical assistance. The Laboratory for biocrystallography (KU Leuven) and the Electron Microscopy Platform \& Bio Imaging Core (KU Leuven, VIB-KU Leuven) are gratefully thanked for assistance with X-ray diffraction measurements and TEM analysis, respectively. M. Monge-Morera thanks the University of Costa Rica (UCR) for the permission to perform research abroad. J. A. Delcour is W. K. Kellogg Chair in Cereal Science and Nutrition at the KU Leuven and beneficiary of Methusalem excellence funding at the KU Leuven.

\section{REFERENCES}

(1) Veraverbeke, W. S.; Delcour, J. A. Wheat Protein Composition and Properties of Wheat Glutenin in Relation to Breadmaking Functionality. Crit. Rev. Food Sci. Nutr. 2002, 42, 179-208.

(2) Wieser, H. Chemistry of Gluten Proteins. Food Microbiol. 2007, 24, $115-119$.

(3) Van Der Borght, A.; Goesaert, H.; Veraverbeke, W. S.; Delcour, J. A. Fractionation of Wheat and Wheat Flour into Starch and Gluten: Overview of the Main Processes and the Factors Involved. J. Cereal Sci. 2005, 41, 221-237.

(4) Day, L.; Augustin, M. A.; Batey, I. L.; Wrigley, C. W. WheatGluten Uses and Industry Needs. Trends Food Sci. Technol. 2006, 17, $82-90$.

(5) Wouters, A. G. B.; Rombouts, I.; Fierens, E.; Brijs, K.; Delcour, J. A. Enzymatically Hydrolyzed Wheat Gluten as a Foaming Agent in Food: Incorporation in a Meringue Recipe as a Proof-of-Concept. J. Food Sci. 2018, 83, 2119-2126.

(6) Jansens, K. J. A.; Rombouts, I.; Grootaert, C.; Brijs, K.; Van Camp, J.; Van der Meeren, P.; Rousseau, F.; Schymkowitz, J.; Delcour, J. A. Rational Design of Amyloid-like Fibrillary Structures for Tailoring Food Protein Techno-Functionality and Their Potential Health Implications. Compr. Rev. Food Sci. Food Saf. 2019, 18, 84105.

(7) Greenwald, J.; Riek, R. Biology of Amyloid: Structure, Function, and Regulation. Structure 2010, 18, 1244-1260.

(8) Schleeger, M.; VandenAkker, C. C.; Deckert-Gaudig, T.; Deckert, V.; Velikov, K. P.; Koenderink, G.; Bonn, M. Amyloids: From Molecular Structure to Mechanical Properties. Polymer 2013, 54, 2473-2488.

(9) Serpell, L. Amyloid Structure. Essays Biochem. 2014, 56, 1-10. 
(10) De Baets, G.; Schymkowitz, J.; Rousseau, F. Predicting Aggregation Prone Sequences in Proteins. Essays Biochem. 2014, 56, $41-52$.

(11) Lambrecht, M. A.; Jansens, K. J. A.; Rombouts, I.; Brijs, K.; Rousseau, F.; Schymkowitz, J.; Delcour, J. A. Conditions Governing Food Protein Amyloid Fibril Formation-Part II: Milk and Legume Proteins. Compr. Rev. Food Sci. Food Saf. 2019, 18, 1277-1291.

(12) Jansens, K. J. A.; Lambrecht, M. A.; Rombouts, I.; Monge Morera, M.; Brijs, K.; Rousseau, F.; Schymkowitz, J.; Delcour, J. A. Conditions Governing Food Protein Amyloid Fibril Formation-Part I: Egg and Cereal Proteins. Compr. Rev. Food Sci. Food Saf. 2019, 18, $1256-1276$

(13) Solomon, A.; Richey, T.; Murphy, C. L.; Weiss, D. T.; Wall, J. S.; Westermark, G. T.; Westermark, P. Amyloidogenic Potential of Foie Gras. Proc. Natl. Acad. Sci. U.S.A. 2007, 104, 10998-11001.

(14) Monge-Morera, M.; Lambrecht, M. A.; Deleu, L. J.; Gallardo, R.; Louros, N. N.; De Vleeschouwer, M.; Rousseau, F.; Schymkowitz, J.; Delcour, J. A. Processing Induced Changes in Food Proteins: Amyloid Formation during Boiling of Hen Egg White. Biomacromolecules 2020, 21, 2218-2228.

(15) Monge-Morera, M.; Lambrecht, M. A.; Deleu, L. J.; Godefroidt, T.; Goos, P.; Rousseau, F.; Schymkowitz, J.; Delcour, J. A. Drying Mode and Hydrothermal Treatment Conditions Govern the Formation of Amyloid-like Protein Fibrils in Solutions of Dried Hen Egg White. Food Hydrocolloids 2020, 112, 106276.

(16) Nilsson, M. Techniques to Study Amyloid Fibril Formation in Vitro. Methods 2004, 34, 151-160.

(17) Delcour, J. A.; Hoseney, R. C. Principles of Cereal Science and Technology, 3rd ed.; AACC International Inc.: St. Paul, MN, USA: Minnesota, 2010.

(18) Rauscher, S.; Baud, S.; Miao, M.; Keeley, F. W.; Pomès, R. Proline and Glycine Control Protein Self-Organization into Elastomeric or Amyloid Fibrils. Structure 2006, 14, 1667-1676.

(19) Chiti, F.; Dobson, C. M. Protein Misfolding, Functional Amyloid, and Human Disease. Annu. Rev. Biochem. 2006, 75, 333366.

(20) Belton, P. S. On the Elasticity of Wheat Gluten. J. Cereal Sci. 1999, 29, 103-107.

(21) Wellner, N.; Mills, E. N. C.; Brownsey, G.; Wilson, R. H.; Brown, N.; Freeman, J.; Halford, N. G.; Shewry, P. R.; Belton, P. S. Changes in Protein Secondary Structure during Gluten Deformation Studied by Dynamic Fourier Transform Infrared Spectroscopy. Biomacromolecules 2005, 6, 255-261.

(22) Athamneh, A. I.; Barone, J. Enzyme-Mediated Self-Assembly of Highly Ordered Structures from Disordered Proteins. Smart Mater. Struct. 2009, 18, 104024.

(23) Lambrecht, M. A.; Monge-Morera, M.; Godefroidt, T.; Vluymans, N.; Deleu, L. J.; Goos, P.; Schymkowitz, J.; Rousseau, F.; Delcour, J. A. Hydrothermal Treatments Cause Wheat Gluten Derived Peptides to Form Amyloid-like Fibrils. J. Ag. Food Chem., accepted for publication.

(24) Ridgley, D. M.; Ebanks, K. C.; Barone, J. R. Peptide Mixtures Can Self-Assemble into Large Amyloid Fibers of Varying Size and Morphology. Biomacromolecules 2011, 12, 3770-3779.

(25) Ridgley, D. M.; Claunch, E. C.; Barone, J. R. The Effect of Processing on Large, Self-Assembled Amyloid Fibers. Soft Matter 2012, 8, 10298-10306.

(26) Mackintosh, S. H.; Meade, S. J.; Healy, J. P.; Sutton, K. H.; Larsen, N. G.; Squires, A. M.; Gerrard, J. A. Wheat Glutenin Proteins Assemble into a Nanostructure with Unusual Structural Features. J. Cereal Sci. 2009, 49, 157-162.

(27) Numata, K.; Kaplan, D. L. Mechanisms of Enzymatic Degradation of Amyloid Beta Microfibrils Generating Nanofilaments and Nanospheres Related to Cytotoxicity. Biochemistry 2010, 49, 3254-3260.

(28) Maurer-Stroh, S.; Debulpaep, M.; Kuemmerer, N.; de la Paz, M. L.; Martins, I. C.; Reumers, J.; Morris, K. L.; Copland, A.; Serpell, L.; Serrano, L.; Schymkowitz, J. W. H.; Rousseau, F. Exploring the
Sequence Determinants of Amyloid Structure Using Position-Specific Scoring Matrices. Nat. Methods 2010, 7, 237-242.

(29) Vassar, P. S.; Culling, C. F. Fluorescent Stains, with Special Reference to Amyloid and Connective Tissues. Arch. Pathol. 1959, 68, 487-498.

(30) Leslie, A. G. W.; Powell, H. R. Processing Diffraction Data with Mosflm. In Evolving Methods for Macromolecular Crystallography; Read, R. J., Sussman, J. L., Eds.; Springer: Dordrecht, The Netherlands, 2007; Vol. 245, pp 41-51.

(31) Kong, J.; Yu, S. Fourier Transform Infrared Spectroscopic Analysis of Protein Secondary Structures. Acta Biochim. Biophys. Sin. 2007, 39, 549-559.

(32) Joye, I. J.; Lagrain, B.; Delcour, J. A. Endogenous Redox Agents and Enzymes That Affect Protein Network Formation during Breadmaking - a Review. J. Cereal Sci. 2009, 50, 1-10.

(33) Bleukx, W.; Roels, S. P.; Delcour, J. A. On the Presence and Activities of Proteolytic Enzymes in Vital Wheat Gluten. J. Cereal Sci. 1997, 26, 183-193.

(34) Zandomeneghi, G.; Krebs, M. R. H.; McCammon, M. G.; Fändrich, M. FTIR Reveals Structural Differences between Native $\beta$ Sheet Proteins and Amyloid Fibrils. Protein Sci. 2009, 13, 3314-3321.

(35) Sipe, J. D.; Cohen, A. S. Review: History of the Amyloid Fibril. J. Struct. Biol. 2000, 130, 88-98.

(36) Sikorski, P.; Atkins, E. New Model for Crystalline Polyglutamine Assemblies and Their Connection with Amyloid Fibrils. Biomacromolecules 2005, 6, 425-432.

(37) Rasheed, F.; Newson, W. R.; Plivelic, T. S.; Kuktaite, R.; Hedenqvist, M. S.; Gällstedt, M.; Johansson, E. Structural Architecture and Solubility of Native and Modified Gliadin and Glutenin Proteins: Non Crystalline Molecular and Atomic Organization. RSC Adv. 2014, 4, 2051-2060.

(38) Lagrain, B.; Brijs, K.; Veraverbeke, W. S.; Delcour, J. A. The Impact of Heating and Cooling on the Physico-Chemical Properties of Wheat Gluten-Water Suspensions. J. Cereal Sci. 2005, 42, 327-333. 